\title{
Prevalence rates and odds ratios of shoulder-neck diseases in different occupational groups
}

\author{
M HAGBERG, ${ }^{1}$ D H WEGMAN ${ }^{2}$
}

From the National Board of Occupational Safety and Health, ${ }^{1}$ Medical Division, Umeå, Sweden, and School of Public Health, ${ }^{2}$ Division of Environmental and Occupational Health Sciences, University of California, Los Angeles, USA

ABSTRACT The aim of the present study was to evaluate the association and impact of occupational exposure and diseases of the shoulder and neck. Prevalence rates, odds ratios, aetiological fractions, and their confidence intervals were computed for pooled and non-pooled data of previous published reports. By comparison with office workers and farmers, dentists had an increased odds ratio for cervical spondylosis (two studies) and for shoulder joint osteoarthrosis. Meat carriers, miners, and "heavy workers" also had significantly higher rates of cervical spondylosis compared with referents. Compared with iron foundry workers, civil servants had a significant odds ratio (4.8) of cervical disc disease and a 0.79 aetiological fraction. Whether this was due to exposure or healthy worker effect was not clear. In four occupational groups with high shoulder-neck load an odds ratio of 4.0 was found for thoracic outlet syndrome with an aetiological fraction of $\mathbf{0 . 7 5}$. Rotator cuff tendinitis in occupational groups with work at shoulder level (two studies) showed an odds ratio of 11 and an aetiological fraction of 0.91 . Keyboard operators had an odds ratio of 3.0 for tension neck syng drome (five studies). Unfortunately, owing to the scanty description of the work task, the exposure. could be analysed only by job title. Examination of published reports shows clearly that certain joos titles are associated with shoulder-neck disorders. High rates and aetiological fractions for rotator cuff tendinitis and tension neck syndrome suggest that preventive measures could be effective. Although job descriptions are brief, the associations noted suggest that highly repetitive shoulder muscle contractions, static contractions, and work at shoulder level are hazardous exposure factors. In reports of cross sectional studies of occupational shoulder-neck disorders presentation of age, exposure, and effect distribution may help for future meta-analysis.

In 1977 Hadler stated that the exposure effect relations of regional musculoskeletal diseases in industry are almost entirely anecdotal, although musculoskeletal diseases rank first in cost to worker's compensation insurance carriers in the United States. ${ }^{12}$ In recent years evidence of an increasing problem with job related shoulder-neck disorders has been reported from Japan and Scandinavia. ${ }^{34}$ This is regarded as a consequence of constrained work postures and repetitive work tasks in industry. An excellent review of occupational cervicobrachial syndromes was published by Waris in 1979, dealing particularly with definition, aetiology, and pathogenesis. $^{5}$ Most epidemiological studies regarding occupational shoulder-neck disorders, however, are cross sectional and present only prevalence rates. Comparisons with referent groups are often made

Accepted 29 September 1986 with no basic epidemiological analysis. The aim of the present investigation was to evaluate the prevalence of shoulder-neck diseases in different occupations presented in previous published studies by calculating prevalence odds ratios, aetiological fractions, and their confidence intervals. Furthermore, several grouped stratified analyses (pooling) was attempted.

\section{Methods}

A survey of the Medlars documentation system was performed for the years between 1966 and 1986 (April); 178 references to occupational shoulder-neck disorders were obtained. Of these, only $20 \%$ contained information of an epidemiological nature. Additional references earlier than 1966 have been gathered by studying reference lists. In the present investigation we have considered only the 21 articles 
Table 1 Study base characteristics, occupational groups job title, sex, age, source-reference number

\begin{tabular}{|c|c|c|c|c|c|c|c|c|}
\hline Occupational group & Sex & No & Mean age & Referents & Sex & No & Mean age & $\operatorname{Ref} \mathrm{No}$ \\
\hline $\begin{array}{l}\text { Miners } \\
\text { Manual workers } \\
\text { "Heavy workers": } \\
\text { Stevedores, slaughterhouse } \\
\text { workers, meat packers, con- } \\
\text { struction workers, foundry } \\
\text { workers, metal workers }\end{array}$ & $\begin{array}{l}\mathbf{M} \\
\mathbf{M} \\
\mathbf{M}\end{array}$ & $\begin{array}{r}84 \\
45 \\
657\end{array}$ & $\begin{array}{l}45^{*} \\
45^{*} \\
43^{*}\end{array}$ & $\begin{array}{l}\text { Office workers } \\
\text { Office workers } \\
\text { "Light workers": } \\
\text { Shop assistants, light } \\
\text { industrial workers, sedentary } \\
\text { workers }\end{array}$ & $\begin{array}{l}\mathbf{M} \\
\mathbf{M} \\
\mathbf{M}\end{array}$ & $\begin{array}{r}42 \\
42 \\
466\end{array}$ & $\begin{array}{l}45^{*} \\
45^{*} \\
41\end{array}$ & $\begin{array}{l}6 \\
6 \\
7\end{array}$ \\
\hline $\begin{array}{l}\text { Miners } \\
\text { Carriers } \\
\text { Dentists } \\
\text { Cotton workers } \\
\text { Cotton workers } \\
\text { Miners } \\
\text { Iron foundry workers } \\
\text { Dockers } \\
\text { Stenotypists } \\
\text { Meat carriers } \\
\text { Lamp assemblers }\end{array}$ & $\begin{array}{l}\mathbf{M} \\
\mathbf{M} \\
\mathbf{M} \\
\mathbf{M} \\
\mathbf{F} \\
\mathbf{M} \\
\mathbf{M} \\
\mathbf{M} \\
\mathbf{F} \\
\mathbf{M} \\
\mathbf{F}\end{array}$ & $\begin{array}{r}84 \\
100 \\
100 \\
113 \\
222 \\
74 \\
858 \\
215 \\
100 \\
54 \\
95\end{array}$ & $\begin{array}{l}51 \\
56 \\
56 \\
57^{*} \\
55^{*} \\
45^{*} \\
44^{*} \\
47^{*} \\
55 \\
40 \\
21\end{array}$ & $\begin{array}{l}\text { Office workers } \\
\text { General population } \\
\text { General population } \\
\text { "Other men" } \\
\text { Civil servants } \\
\text { Office workers } \\
\text { Industrial workers } \\
\text { Teachers and nurses of } \\
\text { handicapped children }\end{array}$ & $\begin{array}{l}\mathbf{M} \\
\mathbf{M} \\
\mathbf{M} \\
\mathbf{M} \\
\mathbf{F} \\
\mathbf{M} \\
\mathbf{F}\end{array}$ & $\begin{array}{r}115 \\
223 \\
55 \\
\\
188 \\
100 \\
100 \\
46\end{array}$ & $\begin{array}{l}57 \\
55 \\
46^{*} \\
\\
39 \\
57 \\
43 \\
27\end{array}$ & $\begin{array}{r}8 \\
8 \\
8 \\
9 \\
9 \\
10 \\
11 \\
12 \\
13 \\
14 \\
15\end{array}$ \\
\hline $\begin{array}{l}\text { Film rolling workers } \\
\text { Office workers } \\
\text { Industrial workers working at } \\
\text { or above shoulder level }\end{array}$ & $\begin{array}{l}\mathbf{F} \\
\mathbf{F}\end{array}$ & $\begin{array}{r}109 \\
74 \\
17\end{array}$ & $\begin{array}{l}25 \\
25 \\
53\end{array}$ & $\begin{array}{l}\text { Industrial workers working } \\
\text { below shoulder level }\end{array}$ & M & 34 & 53 & $\begin{array}{l}15 \\
15 \\
16\end{array}$ \\
\hline $\begin{array}{l}\text { Assembly line packers } \\
\text { Light mechanical industrial } \\
\text { workers, scissors makers }\end{array}$ & $\begin{array}{l}\mathrm{F} \\
\mathrm{F}+ \\
(3 \text { men }\end{array}$ & $\begin{array}{l}152 \\
93 \\
\text { in group) }\end{array}$ & $\begin{array}{l}39 \\
32\end{array}$ & Shop assistants & $\mathbf{F}$ & 133 & 39 & $\begin{array}{l}17 \\
18\end{array}$ \\
\hline $\begin{array}{l}\text { Shipyard welders } \\
\text { Data entry operators }\end{array}$ & $\begin{array}{l}\mathrm{M} \\
\mathrm{F}+ \\
(3 \text { men }\end{array}$ & $\begin{array}{l}131 \\
53 \\
\text { in group) }\end{array}$ & $\begin{array}{l}39 \\
30\end{array}$ & $\begin{array}{l}\text { Office workers } \\
\text { Office workers }\end{array}$ & $\begin{array}{l}\mathbf{M} \\
\mathbf{F} / \mathbf{M}\end{array}$ & $\begin{array}{l}57 \\
55\end{array}$ & $\stackrel{?}{28}$ & $\begin{array}{l}19 \\
20\end{array}$ \\
\hline $\begin{array}{l}\text { Conversational terminal } \\
\text { operators } \\
\text { Typists }\end{array}$ & $\begin{array}{l}\mathrm{M} / \mathrm{F} \\
(54 \mathrm{me}\end{array}$ & $n$ in group) & 34 & Office workers & $\mathbf{F} / \mathbf{M}$ & 55 & 28 & 20 \\
\hline $\begin{array}{l}\text { Typists } \\
\text { Data entry workers }\end{array}$ & $\begin{array}{l}\mathrm{F} \dagger \\
(4 \mathrm{men}\end{array}$ & $\begin{array}{c}78 \\
\text { in group) }\end{array}$ & 34 & Office workers & $\mathbf{F} / \mathbf{M}$ & 55 & 28 & 20 \\
\hline $\begin{array}{l}\text { Data entry workers } \\
\text { Slaughterhouse workers }\end{array}$ & $\begin{array}{l}\dot{\mathbf{F}} \\
\mathbf{M} \dagger\end{array}$ & $\begin{array}{l}104 \\
113 \\
\text { men in group }\end{array}$ & $\begin{array}{r}29 \\
32 \\
\text { p) }\end{array}$ & Office workers & $\mathbf{F}$ & 57 & 31 & $\begin{array}{l}21 \\
22\end{array}$ \\
\hline $\begin{array}{l}\text { Plate workers } \\
\text { Cash register operators } \\
\text { Assembly line workers } \\
\text { Assembly line workers } \\
\text { Dentists } \\
\text { Industrial workers }\end{array}$ & $\begin{array}{l}\mathbf{M} \\
\mathbf{F} \\
\mathbf{M} \\
\mathbf{M} \\
\mathbf{M}\end{array}$ & $\begin{array}{r}188 \\
37 \\
9 \\
83 \\
119 \\
287\end{array}$ & $\begin{array}{l}39 \\
36 \\
29 \\
36 \\
46^{*} \\
39\end{array}$ & $\begin{array}{l}\text { Office workers } \\
\text { Office workers } \\
\text { Office workers } \\
\text { Office workers } \\
\text { Farmers } \\
\text { Industrial workers }\end{array}$ & $\begin{array}{l}\mathbf{M} \\
\mathbf{F} \\
\mathbf{F} \\
\mathbf{M} \\
\mathbf{M} \\
\mathbf{M}\end{array}$ & $\begin{array}{r}57 \\
35 \\
35 \\
27 \\
192 \\
287\end{array}$ & $\begin{array}{l}? \\
31 \\
31 \\
36 \\
46 \\
39\end{array}$ & $\begin{array}{l}23 \\
24 \\
24 \\
24 \\
25 \\
26\end{array}$ \\
\hline
\end{tabular}

*Age estimated from frequency tables.

tSmall number of opposite sex in group.

where the study groups had a diagnosis of shoulderneck disorder that included a physical or laboratory examination (table 1). From each article the prevalence rate of the disease has been compared with that of the referent group given by the author(s). The prevalence rates are expressed as the number of cases per 100 in the groups.

The effects of exposure (usually defined by job title) have been measured by the prevalence odds ratio, the prevalence odds being the probability of being a case divided by the probability of not being a case. The prevalence odds ratio represents an estimate of the incidence rate ratio if the mean duration of disease is identical in the exposed and the non-exposed. ${ }^{27}$ For the prevalence rate ratios, the $95 \%$ confidence intervals were also computed.

If stratified analysis was possible a standardised odds ratio (SOR) was calculated according to Miettinen ${ }^{28}$ and the $95 \%$ confidence interval according to Greenland. ${ }^{29}$ These odds ratios were standard- ised for age or "study", or both, by using the exposed group as the standard population. ${ }^{27} \mathrm{~A}$ test of heterogeneity of effect across studies was made using the method described by Woolfe. ${ }^{30}$

The impact of the exposure (job title) was estimated by the aetiological fraction in the exposed population-that is, the proportion of exposed cases attributable to exposure. The aetiological fraction and its confidence interval was estimated by (OR1)/OR, where $O R$ is the estimated odds ratio. ${ }^{27}$ In the standardised analyses the SOR was substituted for the $\mathrm{OR}$ in the expression for the aetiological fraction. The confidence limits for the aetiological fraction estimates were computed from the estimated variance of the natural $\log$ of the SOR. ${ }^{31}$ To analyse data when zero cells were present, 0.5 was added to each cell.

The diagnostic criteria used for the shoulder-neck disorders varied in the examined studies. A brief description of the different diagnostic criteria is outlined below. 


\section{CER VICAL SPONDYLOSIS}

The diagnosis of cervical spondylosis was based on $\boldsymbol{x}$ ray examination only. Degenerative change of the cervical spine, here termed cervical spondylosis, is characterised by reduced disc height, indicating disc degeneration, and by proliferation of bone tissue (spurs or osteophytes). Hult includes osteophytes as a sign of disc degeneration. ${ }^{7}$ Lawrence distinguishes between osteoarthrosis and disc degeneration of the cervical spine.' We regard osteoarthrosis in the cervical spine as spondylosis. For the early studies of Schroter severe "osteochondrose und spondylose" have been analysed as spondylosis according to the analysis performed by the author. ${ }^{813}$ As the report on meat carriers presented only frequencies of spondylosis for each cervical level we computed the odds ratio standardised to cervical level. In summary our concept of cervical spondylosis is that of degenerative changes in the cervical spine, radiographically seen as spurs or a reduction in disc height.

CER VICAL SYNDROME (cervical disc disease)

The diagnosis of cervical syndrome was based on interview and physical examination. Dockers, civil servants, 12 and iron foundry workers ${ }^{11}$ had an interview about musculoskeletal pain. When symptoms were present a simple clinical examination was made to localise the site and cause of the pain. ${ }^{32}$ Pain had to be present in the neck, radiating along the distribution of a spinal root at some time. For assembly line packers, shop assistants, slaughterhouse workers, scissors makers, and data entry operators the diagnostic criteria were neck pain radiating to one or both arms and numbness in the hands in addition to limitation of neck movement and radiating pain provoked by test movements. ${ }^{33}$ Pain in the neck radiating to the arm with a segmental distribution was our concept of cervical syndrome.

\section{THORACIC OUTLET SYNDROME (TOS)}

Cash register operators, assembly workers, and their referents were diagnosed as having symptoms of TOS if the abduction external rotation test (Roos's test ${ }^{34}$ ) was positive. ${ }^{24}$ Positives were those who experienced pain, early fatigue, tingling, or paraesthesias during the three minute test. Tenderness over the brachial plexus in the suprachvicular fossa was also sought. Whether both symptoms in the test and tenderness of the brachial plexus or either one was needed for the classification "symptoms of TOS" is not stated in the article. ${ }^{24}$ For assembly line packers, shop assistants, and scissors makers the diagnostic criteria were subjective symptoms of pain radiating in the hand and a positive Moreley's sign (tenderness in the supraclavicular fossa). In addition, drooping shoulder or Adson's test (radial pulse impairment or loss on head rotation) had to be present. ${ }^{33}$ The criteria used in the examination of slaughterhouse workers were pain $\vec{Z}$ radiating to hand and a positive Roos's test. In the study of Silverstein the criteria were paraesthesiass (usually in the ulnar distribution in hand and arm)? positive Adson, hyperabduction or costoclavicularo test, and decreased grip strength. In summary, the concept of TOS is that of a compression of the neu rovascular bundle at the shoulder-thoracal junction, The criteria differ among researchers as to the type and number of clinical tests that have to be positive. We have included in TOS a positive Roos's test as $\vec{a}-\overrightarrow{-}$ single criterion which may be an early and sensitive indicator even though the specificity of the test is low

SHOULDER JOINT OSTEOARTHROSIS

This diagnosis was based solely on $x$ ray findings. The ${ }^{6}$ criteria of shoulder joint changes were not presented in the only article concerned with this disease. ${ }^{25}$ Our $_{0}$ concept of shoulder joint osteoarthrosis is that of $\mathrm{a}^{-}$ reduction in the articular cartilage height and sclero- $\vec{c}$ sis in the structures of the glenohumeral joint.

ROTA TOR CUFF TENDINITIS (supraspinous tendinitis)

Shipyard welders, plate workers, and male offige $\overrightarrow{0}$ workers had the following criteria for supraspinogis tendinitis: localised shoulder pain and tenderness $f_{\square}$ the humeral head. Pain with isometric contraction, limitations of active range of movement, and reduction of gross power were measured but it is not stated whether these signs were required for the diagno- $\frac{0}{8}$ sis. ${ }^{1923}$ For slaughterhouse workers the diagnostic criteria were pain in the shoulder region and localo tenderness. ${ }^{22}$ The criteria for scissors makers, assem- 3 bly line packers, and data entry operators were local pain, local tenderness, pain during abduction, and:limited active abduction. ${ }^{33}$ In the case-referent study of industrial workers working with the hands at or 3 above shoulder level the criteria were local pain ando tenderness in addition to pain at isometric abduc tion. ${ }^{16}$ In summary, rotator cuff tendinitis waso regarded as localised shoulder pain with tenderness over the humeral head.

\section{TENSION NECK SYNDROME}

A constant feeling of fatigue or stifiness, or both, inf the neck plus one more subjective symptom-for example, neck pain or headache in addition to signs? of at least two tender spots or palpable hardenings, of both, plus muscle tightness in neck movements-were the diagnostic criteria of tension neck syndrome fof the Finnish studies of slaughterhouse workers, dato entry operators, assembly line packers, shop assis:tants, and female office workers. ${ }^{33}$ For the Swiss data 
Table 2 Cervical spondylosis. Prenalence rates (momber of casses per 100 in group) and adt ratios of radiographically verified degenerative charges in the cervicel spine

\begin{tabular}{|c|c|c|c|c|c|c|c|c|}
\hline Decipationed grous & $\operatorname{sex}$ & $\boldsymbol{R} \boldsymbol{I}$ & $\boldsymbol{m}$ & OR & $95 \mathrm{CI}$ & $E F$ & $95 \mathrm{CI}$ & $R \in f N o$ \\
\hline 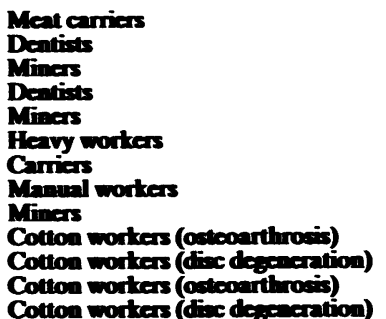 & $\begin{array}{l}\mathbf{M} \\
\mathbf{M} \\
\mathbf{M} \\
\mathbf{M} \\
\mathbf{M} \\
\mathbf{M} \\
\mathbf{M} \\
\mathbf{M} \\
\mathbf{F} \\
\mathbf{M} \\
\mathbf{M}\end{array}$ & $\begin{array}{l}84 \\
42 \\
76 \\
50 \\
54 \\
55 \\
23 \\
42 \\
13 \\
31 \\
56 \\
41 \\
78\end{array}$ & $\begin{array}{l}33 \\
14 \\
51 \\
31 \\
38 \\
42 \\
14 \\
38 \\
14 \\
38 \\
70 \\
53 \\
83\end{array}$ & $\begin{array}{l}8-4 \\
5-3 * \\
4-5^{*} \\
4-0 \\
1-9 \\
1-7 * \\
1-8 \\
1-2 \\
091 \\
0-75 \\
069 \\
061 \\
0-57\end{array}$ & $\begin{array}{l}4-5-16 \\
2-7-10 \\
1-5-13 \\
2-0-7-9 \\
0-89-2-8 \\
1-2-2-3 \\
0-89-3-7 \\
0-51-2-8 \\
0-10-2-1 \\
0-50-1-1 \\
0-47-10 \\
0-63-10 \\
0-30-1-1\end{array}$ & $\begin{array}{l}0.88 \\
0-81 \\
0-78 \\
0-75 \\
0-40\end{array}$ & $\begin{array}{l}0-74-094 \\
0-63-0.90 \\
0-34-0.92 \\
0-50-0-87 \\
0-16-0-57\end{array}$ & $\begin{array}{r}14 \\
8 \\
10 \\
25 \\
6 \\
7 \\
8 \\
6 \\
8 \\
9 \\
9 \\
9 \\
20\end{array}$ \\
\hline
\end{tabular}

R1 = rate study grop, R0 = rate referent grom, OR = odds ratio, EF = actiological fraction in exposed group, 95 C = $95 \%$ confidence interval, Ref No = source as manber in reference list.

Afe standardived odds ratio.

entry operators, "conversational terminal operators," typists, and office workers the medical finding listed as "tendomyotic pressure pains in shoulders and neck" was regarded as tension neck syndrome. ${ }^{20}$ In the study of film rolling workers, lamp assemblers, office workers, teachers, and nurses of handicapped children by Onishi et al ${ }^{15}$ we used the group who had shoulder stiffiness in addition to tenderness threshold of the upper trapezius muscle up to $1.50 \mathrm{~kg} / \mathrm{cm}^{2}$ as having tension neck syndrome. Silverstein defined tension neck syndrome for industrial workers as neck pain or stiffiness, muscle tightness, palpable hardenings, and tender spots. ${ }^{26}$ Furthermore, pain on resisted neck lateral fiexion and rotation was required. In summary our concept of tension neck syndrome was pain in the shoulder or neck in addition to tenderness over the descending part of the trapezius muscle.

\section{POOLED STUDIES}

The exposure in most studies was given only by job title or by industry. ${ }^{16}$ For the scissors makers a job analysis was presented and a dose response analysis was carried out. ${ }^{18}$ It was not possible, therefore, to group studies for exposure otherwise than by the type of job within each diagnostic group. The objective of grouping (pooling) studies was to evaluate the total effect and impact of exposure. This was done by stan- dardised analysis controlling for variables such as age and sex when available. A serious limitation for this analysis was that the referent groups may have had unidentified differences in exposures. The male and female cotton workers with "osteoarthrosis" and disc degeneration were pooled into a group of cotton workers.9

Thoracic outlet syndrome-Occupational groups, where the work tasks were assumed to contain highly repetitive arm movements, were pooled into a group of "repetitive arm movement jobs." These four pooled occupational groups were assembly line packers, male and female assembly line workers, and cash register operators. ${ }^{17} 24$

Rotator cuff tendinitis-Two studies were pooled into a "shoulder level jobs" group, ${ }^{19} 23$ since the workers had work tasks at or above shoulder level. These workers consisted of shipyard welders and plate workers.

Tension neck syndrome-A pooled group"keyboard operators" - was created, consisting of four occupational groups of VDT operators and typists. 2021

\section{Resints}

CER VICAL SPONDYLOSIS

Odds ratios significantly exceeding 1 were found for

Table 3 Andysis of pooled studies

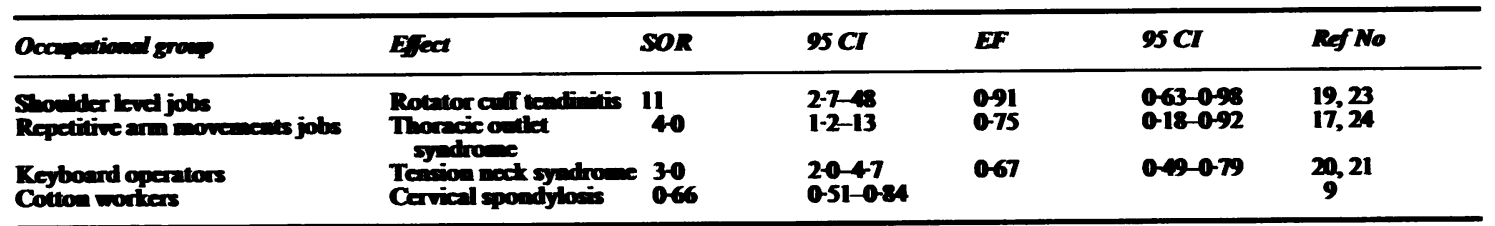


Table 4 Cervical syndrome. Prevalence rates (number of cases per 100 in group) and odds ratios of cervical syndrome (cervical disc disease). (Referents within parentheses not given by the original author of the study group)

\begin{tabular}{|c|c|c|c|c|c|c|c|c|c|}
\hline Occupational group & Sex & Referents & $\boldsymbol{R} \mathbf{I}$ & $R O$ & $O R$ & $95 \mathrm{CI}$ & $E F$ & $95 C I$ & $\operatorname{Ref} N o$ \\
\hline $\begin{array}{l}\text { Slaughterhouse workers } \\
\text { Scissors makers } \\
\text { Civil servants } \\
\text { Data entry operators } \\
\text { Dockers } \\
\text { Assembly line packers } \\
\text { Iron foundry workers }\end{array}$ & $\begin{array}{l}\mathbf{M} \\
\mathbf{F} \\
\mathbf{M} \\
\mathbf{F} \\
\mathbf{M} \\
\mathbf{F} \\
\mathbf{M}\end{array}$ & $\begin{array}{l}\text { (Assembly line packers) } \\
\text { (Assembly line packers) } \\
\text { (Iron foundry workers) } \\
\text { Office workers } \\
\text { Civil servants } \\
\text { Shop assistants } \\
\text { (Civil servants) }\end{array}$ & $\begin{array}{l}5 \\
3 \\
5 \\
1 \\
2 \\
1 \\
1\end{array}$ & $\begin{array}{l}1 \\
1 \\
1 \\
2 \\
5 \\
2 \\
5\end{array}$ & $\begin{array}{l}8 \cdot 5 \\
5 \cdot 0 \\
4 \cdot 8 * \\
0 \cdot 54 \\
0 \cdot 47 \\
0 \cdot 27 \\
0 \cdot 07\end{array}$ & $\begin{array}{l}1 \cdot 0-71 \\
0.52-49 \\
1.8-13 \\
0.03-8.9 \\
0.14-1 \cdot 5 \\
0.03-2.8 \\
0.02-0.26\end{array}$ & $\begin{array}{l}0.88 \\
0.79\end{array}$ & $\begin{array}{l}0-0.99 \\
0.44-0.92\end{array}$ & $\begin{array}{l}17,22 \\
18,22 \\
11,12 \\
21 \\
12 \\
17 \\
11,12\end{array}$ \\
\hline
\end{tabular}

R1, R0, OR, 95 CI, EF, Ref No, *, see table 2.

Table 5 Thoracic outlet syndrome. Prevalence rates (number of cases per 100 in group) and odds ratios for thoracic outlet syndrome (TOS). (Referents within parentheses not given by the original author of the study group)

\begin{tabular}{|c|c|c|c|c|c|c|c|}
\hline Occupational group & Sex & Referents & $R I$ & $\boldsymbol{R O}$ & $O R$ & $95 \mathrm{CI}$ & $\operatorname{Ref} N o$ \\
\hline $\begin{array}{l}\text { Assembly line packers } \\
\text { Assembly line workers } \\
\text { Assembly line workers } \\
\text { Slaughterhouse workers } \\
\text { Cash register operators }\end{array}$ & $\begin{array}{l}\mathbf{F} \\
\mathbf{M} \\
\mathbf{F} \\
\mathbf{M} \\
\mathbf{F}\end{array}$ & $\begin{array}{l}\text { Shop assistants } \\
\text { Office workers } \\
\text { Office workers } \\
\text { (Scissors makers) } \\
\text { Office workers }\end{array}$ & $\begin{array}{r}3 \\
14 \\
44 \\
1 \\
32\end{array}$ & $\begin{array}{r}0 \\
0 \\
14 \\
0 \\
17\end{array}$ & $\begin{array}{l}10 \\
9 \cdot 6 \\
3 \cdot 9 \\
2 \cdot 5 \\
1 \cdot 7\end{array}$ & $\begin{array}{l}0 \cdot 54-182 \\
0 \cdot 55-168 \\
0 \cdot 80-19 \\
0 \cdot 10-62 \\
0 \cdot 54-5 \cdot 3\end{array}$ & $\begin{array}{l}17 \\
24 \\
24 \\
18,22 \\
24\end{array}$ \\
\hline
\end{tabular}

R1, R0, OR, 95 CI, Ref No, see table 2.

Table 6 Rotator cuff tendinitis. Prevalence rates (number of cases per 100 in study group) and odds ratios of rotator cuff tendinitis (supraspinate tendinitis). (Referents within parentheses not given by the original author of the study group)

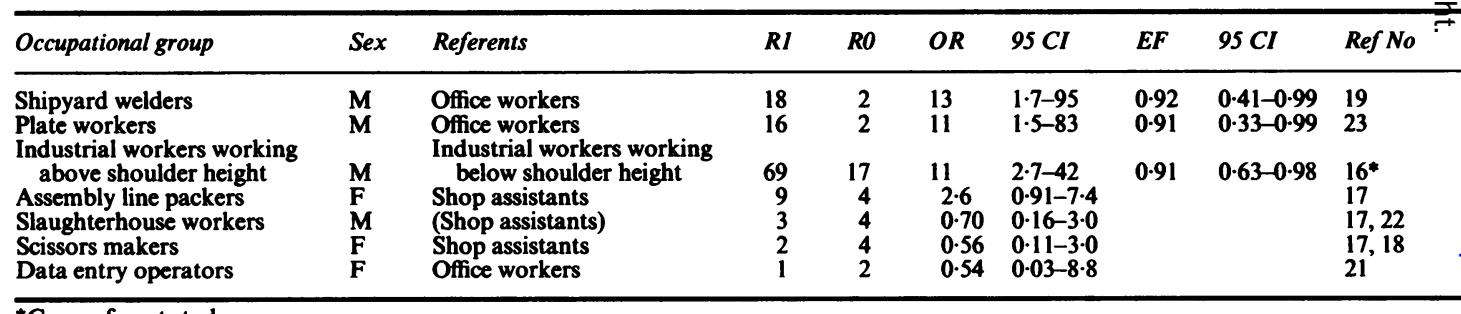

* Case-referent study.

R1, R0, OR, 95 CI, EF, Ref No, see table 2.

meat carriers, dentists (two studies), miners, and heavy workers (table 2). The frequency of degeneration and osteoarthrosis was less among cotton workers than among the general population (table 3). The highest aetiological fraction for cervical spondylosis was $\mathbf{0 . 8 8}$ for meat carriers. Dentists, miners, and heavy workers had aetiological fractions of $0.75-0.81$, $0 \cdot 78$, and $0 \cdot 40$, respectively (table 2 ).

\section{CER VICAL SYNDROME}

The reported point prevalence rates of cervical syndrome are low, ranging between 1 and 5 (table 4). A prevalence odds ratio of 4.8 was found for civil servants compared with iron foundry workers; the aetiological fraction was 0.79 (table 4 ).
THORACIC OUTLET SYNDROME (TOS)

The rates varied considerably, ranging from 44 for 3 female assembly line workers (table 5) to 0.3 foro industrial workers as described by Silverstein. ${ }^{26}$ None of the studies showed a significant odds ratio. When the four groups were pooled a significant SOR of $4 \cdot 0$. was found; the aetiological fraction was 0.75 (table 3 ). $\%$

\section{SHOULDER JOINT OSTEOARTHROSIS}

Only one cross sectional study of dentists and farmers was found in which radiographs of the glenohumeral joint were taken in addition to radiographs of the cer- - 등

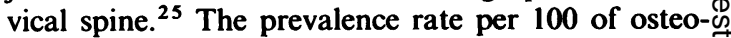
arthrosis in the shoulder for dentists was 13 with an age SOR of 4.2 when contrasted with farmers. The 
Table 7 Tension neck syndrome. Prevalence rates (number of cases per 100 in group) and odds ratios for tension neck syndrome (shoulder muscle tenderness and pain). (Referents within parentheses not given by the original author of the study group)

\begin{tabular}{|c|c|c|c|c|c|c|c|c|c|}
\hline Occupational group & Sex & Referents & $R I$ & $R O$ & $O R$ & $95 C I$ & $E F$ & $95 \mathrm{CI}$ & $\operatorname{Ref} \mathrm{No}$ \\
\hline Filmrolling workers & $\mathbf{F}$ & $\begin{array}{l}\text { Teachers and nurses of } \\
\text { handicapped children }\end{array}$ & 100 & 65 & 118 & $6.9-1000$ & 0.99 & $0.85-1$ & 15 \\
\hline $\begin{array}{l}\text { Female industrial workers } \\
\text { Lamp assemblers }\end{array}$ & $\mathbf{F}$ & $\begin{array}{l}\text { Male industrial workers } \\
\text { Teachers and nurses of } \\
\text { handicapped children }\end{array}$ & $\begin{array}{r}8 \\
91\end{array}$ & $\begin{array}{r}1 \\
65\end{array}$ & $\begin{array}{l}5 \cdot 9 \\
5 \cdot 1\end{array}$ & $\begin{array}{l}2 \cdot 0-17 \\
2 \cdot 0-13\end{array}$ & $\begin{array}{l}0.83 \\
0.80\end{array}$ & $\begin{array}{l}0.50-0.94 \\
0.50-0.92\end{array}$ & $\begin{array}{l}26 \\
15\end{array}$ \\
\hline $\begin{array}{l}\text { Data entry operators } \\
\text { Typists } \\
\text { Scissors makers } \\
\text { Conversational terminal }\end{array}$ & $\begin{array}{l}\mathbf{F} \\
\mathbf{F}\end{array}$ & $\begin{array}{l}\text { Office workers } \\
\text { Office workers } \\
\text { (Shop assistants) }\end{array}$ & $\begin{array}{l}38 \\
35 \\
61\end{array}$ & $\begin{array}{l}11 \\
11 \\
28\end{array}$ & $\begin{array}{l}4 \cdot 9 \\
4 \cdot 2 \\
4 \cdot 1\end{array}$ & $\begin{array}{l}1 \cdot 8-13 \\
1 \cdot 6-11 \\
2 \cdot 3-7 \cdot 2\end{array}$ & $\begin{array}{l}0.80 \\
0.76 \\
0.76\end{array}$ & $\begin{array}{l}0.44-0.92 \\
0.38-0.91 \\
0.57-0.86\end{array}$ & $\begin{array}{l}20 \\
20 \\
17,18\end{array}$ \\
\hline $\begin{array}{l}\text { operators } \\
\text { Data entry operators } \\
\text { Office workers }\end{array}$ & $\begin{array}{l}\mathbf{F} \\
\mathbf{F} \\
\mathbf{F}\end{array}$ & $\begin{array}{l}\text { Office workers } \\
\text { Office workers } \\
\text { Teachers and nurses of } \\
\text { handicapped children }\end{array}$ & $\begin{array}{l}28 \\
47 \\
80\end{array}$ & $\begin{array}{l}11 \\
28 \\
65\end{array}$ & $\begin{array}{l}3 \cdot 2 \\
2 \cdot 3 \\
2 \cdot 1\end{array}$ & $\begin{array}{l}1 \cdot 2-8 \cdot 2 \\
1 \cdot 1-4 \cdot 6 \\
0 \cdot 92-4 \cdot 8\end{array}$ & $\begin{array}{l}0.69 \\
0.57\end{array}$ & $\begin{array}{l}0.17-0.88 \\
0.09-0.78\end{array}$ & $\begin{array}{l}20 \\
21 \\
15\end{array}$ \\
\hline $\begin{array}{l}\text { Assembly line packers } \\
\text { Slaughterhouse workers }\end{array}$ & $\begin{array}{l}\mathbf{F} \\
\mathbf{M}\end{array}$ & $\begin{array}{l}\text { Shop assistants } \\
\text { (Shop assistants) }\end{array}$ & $\begin{array}{r}38 \\
5\end{array}$ & $\begin{array}{l}28 \\
28\end{array}$ & $\begin{array}{l}1.6 \\
0.15\end{array}$ & $\begin{array}{l}0.94-2.6 \\
0.06-0.37\end{array}$ & & & $\begin{array}{l}17 \\
17,22\end{array}$ \\
\hline
\end{tabular}

* Case-referent study.

R1, R0, OR, 95 CI, EF, Ref No, see table 2.

$95 \%$ confidence interval was $2 \cdot 1-8 \cdot 5$ and the aetiological fraction 0.76 with confidence intervals of 0.53-0.88.

\section{ROTATOR CUFF TENDINITIS}

The reported prevalence rates among shipyard welders and plate workers are rather high, 18 and 16, respectively (table 6 ). The odds ratio for the two pooled studies of occupational groups with work tasks at shoulder level was 11 with an aetiological fraction of 0.91 (table 3).

\section{TENSION NECK SYNDROME}

Tension neck syndrome had the highest rates of all shoulder-neck diseases studied, reaching a point prevalence rate of 100 in Japanese filmrolling workers (table 7). Women tended to have higher rates of tension neck syndrome than men. The odds ratio for selected female industrial workers in the United States compared with male industrial workers was 5.9. Odds ratios significantly higher than 1.0 were found for datà entry workèrs in two different studies, typists, assembly line packers, scissors makers, lamp assemblers, and in film rolling workers. In the pooled analysis of keyboard operators the SOR was 3.0 with an aetiological fraction of 0.67 (table 3).

\section{Discussion}

It is important to note that this evaluation of published data suffers from the incomplete or inadequate controlling for confounding factors such as sex or age in most studies. When performing a cross sectional study the aim is to investigate whether the group under study has an excess prevalence of a disorder that could be related to the characteristic of the occupational exposure of the group. The power has also to be considered when evaluating these studies. The non-significant exposure effect relations reported for thoracic outlet syndrome and cervical disc disease may be due to low power-that is, the prevalence rates of the diseases are low and thus the sample sizes needed to detect a risk must be large (figure). For tension neck syndrome which is more common the sample size needed for risk assessment is considerably less (figure). If the disorder disables the worker the prevalence rate of the disorder will be affected by a healthy worker effect. The low prevalence and prevalence odds ratios of cervical syndrome (cervical disc disease) may possibly be inaccurate owing to a healthy worker effect, since an episode of cervical syndrome may disable a worker or force a transfer from

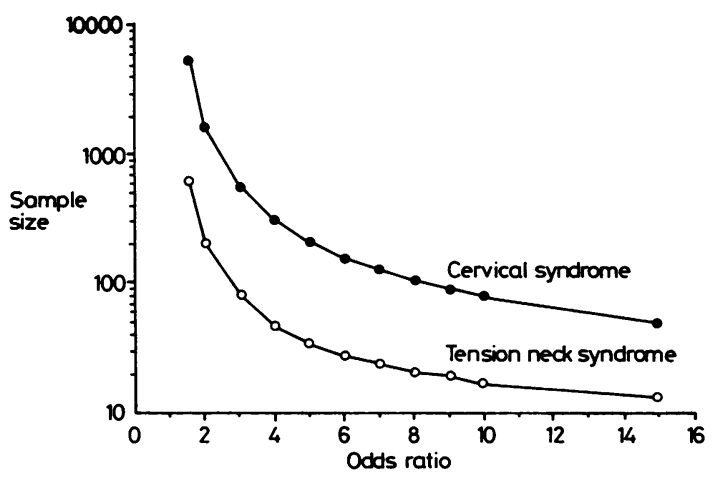

Sample size for both study and referent group needed to detect with $90 \%$ probability the odds ratios between 1.5 and $15(p<0.05)$ for cervical syndrome assumed to have rate (prevalence) 2 per 100 in general population and tension neck syndrome assumed to have rate (prevalence) of 25 per 100 in general population. ${ }^{35}$ 
a job with high load on the cervical spine. By contrast, when the shoulder-neck disease causes little or no disability, high prevalence rates may occur. The reported high prevalence of tension neck syndrome may partly be due to the fact that this disorder causes little or late disability.

In the epidemiological analysis we urge that the raw data are presented stratified by age and exposure. Furthermore, the odds ratios and their confidence intervals should also be presented. Computation of the aetiological fraction is helpful for the evaluation of the impact of exposure. If the time of onset of symptoms is assessed in a cross sectional study it is then possible to compute the incidence densities. By comparing the incidence densities for different years in both the study and the referent groups it is possible to estimate the magnitude of the healthy worker effect as suggested by Punett and Robins. ${ }^{36}$ The exposure in the reports we examined was most often given by job title or industry. A detailed description regarding working postures, arm and head movements, material handled, and work organisation would have made comparisons between studies easier. A job title such as "office worker" describes a potentially large variety of occupational tasks. Office workers may be supervisors without repetitive movements or constrained work postures but may also be data entry operators. It was not possible in the present study to examine the effect of exposure from physical load but only the exposure attributable to job title. In most of the examined reports the hypothesis of exposure-efect relation was that a certain job title was at risk for a disorder, the exposure as load on the shoulder and neck was usually not quantified in any way. This makes it hard to conclude what the exposure characteristics are that separate the study group from the referent group. We suggest that the exposure of the study and the referent groups should be given, preferably in parametric quantitative measures. For local load evaluation information is necessary on working postures, arm and head movements, weight, shape and frequency of object handled, and work organisation (how long are the work periods between rests and pauses, for example). Some standardised techniques have been described for job analysis, most are time consuming, however. There is a great need for a standardised simple way to assess physical exposure. The efiect measures examined in this paper were diseases (where we have information about them) which were better described than exposures but not well understood in terms of precursors of disabiity or indicators of decreased quality of life. The use of cervical spondylosis as a measure of efiect may be questioned since the correlation between radiographic spondylosis and symptoms is poor. ${ }^{37} 36$ We recommend that the criteria for the effect (disease) be presented in detail in future. Identification of shoulder-neck diseases may not be optimal when the objective is to get early warnings of exposures that may cause disability and pain. Other effect measures? could include standardised function tests (measure? of muscle strength and endurance), serological test? (creatine kinase), or recording of changes of the activ? ities of daily life (hobbies, sport).

Judging from recent studies, the prevalence of reported complaints consistent with a disorder is higher when the symptoms alone are compared with symptoms plus physical examination. The prevalence: rate of tension neck syndrome among male industria $P$ workers in the United States was reported to be $4-9 \%$ from interview data alone. When cases confirmed by a positive physical examination were counted, thet rate dropped to $1-4 \% .^{26}$ Even though there is littico misclassification of the shoulder-neck diseases whem physical examination is performed, those diseases may not be the appropriate outcome measure.

\section{CER VICAL SPONDYLOSIS}

The hypothesis of the exposure causing cervical spont dylosis is that of a high load on the cervical spine There were occupational groups with a significan? odds ratio above 1-0, meat carriers, dentists, miners and heavy workers. The meat carriers carried torip meat partially on their heads, placing a high loadson the cervical spine, ${ }^{8}$ which is consistent with findigigs of an increased rate of cervical spondylosis in Jamaican rural population who carried burdens on their heads. ${ }^{39}$ An increased load on the cervical sping in miners could possibly occur for miners due to the effect of helmet or extreme positions of the cervicat spine or both. Sources for a high load on the cervicai spine, however, have not been described for dentist? and heavy workers. Frequent extreme positions of the cervical spine may possibly occur for dentists, giving a high load on the cervical spine. The finding of less cervical spondylosis among cotton workers compareat with the general population is obscure. This canno? simply be explained by a healthy worker efiect sinces symptoms due to cervical spondylosis are rare. Fur? thermore, the possibility that other cocupations with high load on the cervical spine (miners, for example)? in the general population could be the cause of this healthy worker efiect is not likely since the female cotton workers showed the same tendencies for less spondylosis compared with the general population. N

\section{CER VICAL SYNDROME}

The exposure hypothesised to give cervical syndrome (or signs and symptoms consistent with cervical syne drome) is extreme forward flexion of the cervical spine. 4041 If the civil servants had work posture with flexed cervical spine this could cause symptoms con- 
forming to the cervical syndrome. Another plausible explanation for the significant odds ratio above one, however, would be that cervical syndrome would be more disabling for an iron foundry worker compared with a civil servant. Thus the finding of raised odds ratio in clerical workers may represent a healthy worker effect operating for iron foundry workers compared with civil servants.

\section{THORACIC OUTLET SYNDROME (TOS)}

Rates for TOS varied considerably from 0.3 to 44 ; this may reflect not only difference in the true rates but also in diagnostic criteria. Individually, none of the studies showed a significant exposure-effect relation. Under the hypothesis that short cycle repetitive arm work gives a static load on the neck and shoulder girdle muscles that may promote a thoracic outlet syndrome (perhaps only in individuals with constitutional factors such as musculoskeletal abnormalities) the pooled analysis showed a significant odds ratio of an exposure-effect relation.

\section{GLENOHUMERAL JOINT OSTEOARTHROSIS}

Mechanical stresses may be one aetiological factor in osteoarthrosis. ${ }^{42}$ Nevertheless, glenohumeral joint load among dentists has not been documented as an explanation for the significant odds ratio of shoulder joint osteoarthrosis. It should be noted that osteoarthrosis of the glenohumeral joint is rare before the sixth decade in the general population ${ }^{43}$ and that the correlation between radiographic signs and symptoms is poor. ${ }^{445}$

\section{ROTATOR CUFF TENDINITIS}

Impingement of the rotator cuff tendons under the coracoacromial arch have been suggested as the main cause of rotator cuff tendinitis. ${ }^{46}$ The exposure giving impingement is a work task demanding raising of the arms. The three occupational groups studied with work likely to be at or above shoulder level had a significantly high odds ratio and aetiological fraction for rotator cuff tendinitis.

\section{TENSION NECK SYNDROME}

The hypothesised exposure causing tension neck syndrome is static tension (contraction) of the neck and shoulder-neck muscles. ${ }^{47}$ The pooled analysis showed a high odds ratio for the "keyboard operators." This may reflect the exposure of a static load on the upper trapezius muscle measured by EMG. ${ }^{48}$

This examination of reports of prevalence of shoulder and neck disorders has clearly shown that certain job titles are associated with shoulder-neck disorders. Furthermore, for some of the disorders, both the rates and the aetiological fractions in the exposed groups are high, implying that occupational preventive mea- sures could be effective. Although job analysis was not done for most of the studies, the basis for grouping studies points toward specific exposure factors such as highly repetitive contractions in the shoulder muscles, work at or above shoulder level, static contractions, and possibly head posture as causative factors in shoulder-neck disorders.

We thank Professor Hal Morgenstern, School of Public Health, Division of Epidemiology, UCLA, for supplying us with a Fortran program for analysis of cross sectional studies and for valuable comments on this manuscript.

This study was supported by grants from the Swedish Work Environment Fund.

\section{References}

1 Hadler NM. Industrial rheumatology, clinical investigation into influence on pattern of use of regional musculoskeletal disease. Arthritis Rheum 1977;20:1019-25.

2 Cunningham LS, Kelsey JL. Epidemiology of musculoskeletal impairments and associated disability. Am $J$ Public Health 1984;74:574-9.

3 Maeda K, Horiguchi S, Hosokawa M. History of the studies on occupational cervicobrachial disorders in Japan and remaining problems. J Hum Ergol 1982;11:17-29.

4 Westgaard RH, Aarás A. Postural muscle strain as a causal factor in the development of musculo-skeletal illnesses. Applied Ergonomics 1984;15:162-74.

5 Waris P. Occupational cervicobrachial syndromes. Scand J Work Environ Health 1979;6 suppl 3:3-13.

6 Kellgren JH, Lawrence JS. Rheumatism in miners. Br J Ind Med 1952;9:197-207.

7 Hult L. Cervical, dorsal and lumbar spinal syndromes. Acta Orthop Scand 1954: suppl 17.

8 Schroter G. Hat die berufliche Belastung Bedeutung für die Entsthung oder Verschlimmerung der Osteochondrose und Spondylose der Halswirbelsaule. Deutsche Gesundheitswesen 1959;14:174-7.

9 Lawrence JS. Rheumatic in cotton operatives. Br J Ind Med 1961;18:270-6.

10 Newell DJ. Prevalence, aetiology and treatment of pain in the neck and arm. Transactions of the Society of Occupational Medicine 1967;17:104-6.

11 Partridge REH, Andersson JAD, McCarthy MA, Duthie JRR. Rheumatic complaints among workers in iron foundries. Ann Rhewm Dis 1968;27:441-3.

12 Partridge REH, Duthic JJR. Rheumatism in dockers and civil servants: a comparison of heavy manual and sedentary workers. Ann Rheum Dis 1968;27:559-67.

13 Schroter G. Zur frage der Uberbelastungsschaden der Halswirbelsaule bei Stenotypistinnen. Z Gesamte Hyg 1968;14:333-7.

14 Schroter G, Rademacher W. Die Bedeutung von Belastung und aussergewhonlicher Haltung für das Entstehen von Verschkiss-schaden der HWS - dargestellt an einem Kollektive von Fleischabträgern. Z Gesamte Hyg 1971;17:841-3.

15 Onishi N, Nomura H, Sakai K, Yamamoto T, Hirayama K, Itani T. Shoulder muscle tenderness and physical features of female industrial workers. J Hum Ergol 1976;5:87-102.

16 Bjelle A, Hagberg M, Michaelson G. Clinical and ergonomic factors in prolonged shoulder pain among industrial workers. Scand J Work Environ Health 1979;5:205-10.

17 Luopajarvi T, Kuorinka I, Virolainen M, Holmberg M. Prevalence of tenosynovitis and other injuries of the upper extremities in repetitive work. Scand $J$ Work Environ Health 
1979;6 suppl 3:48-55.

18 Kuorinka I, Koskinen P. Occupational rheumatic diseases and upper limb strain in manual jobs in a light mechanical industry. Scand J Work Environ Health 1979;6 suppl 3:39-47.

19 Herberts P, Kadefors R, Andersson G. Shoulder pain in industry: an epidemiological study of welders. Acta Orthop Scand 1981;52:299-306.

20 Hunting W, Laubli T, Grandjean E. Postural and visual loads at VDP workplaces. Ergonomics 1981;24:917-31.

21 Kukkonen R, Luopajarvi T, Riihimaki V. Prevention of fatigue amongst data entry operators. In: Kvalseth TO, ed. Ergonomics of workstation design. London: Butterworths, 1983:28-34.

22 Viikari-Juntura E. Neck and upper limb disorders among slaughterhouse workers. Scand J Work Environ Health 1983;9: 283-90.

23 Herberts P, Kadefors R, Högfors C, Sigholm G. Shoulder pain and heavy manual labor. Clin Orthop 1984;191:168-78.

24 Sällström J, Schmidt H. Cervicobrachial disorders in certain occupations with special reference to compression in the thoracic outlet. Am J Ind Med 1984;6:45-52.

25 Katevuo K, Aitasalo K, Lehtinen R, Pietila J. Skeletal changes in dentists and farmers in Finland. Community Dent Oral Epidemiol 1985;13:23-5.

26 Silverstein BA. The prevalence of upper extremity cumulative trauma disorders in industry. Ann Arbor: University of Michigan, Occupational health and Safety Engineering, 1985. (Thesis.)

27 Kleinbaum DG, Kupper LL, Morgenstern H. Epidemiologic research. Belmont: Lifetime Learning Publications, 1982.

28 Miettinen OS. Standardization of risk ratios. Am J Epidemiol 1972;96:383-8.

29 Greenland S. Interpretation and estimation of summary ratios under heterogeneity. Statistics in Medicine 1982;1:217-27.

30 Woolf B. Statistical methods for rates and proportions. 2nd ed. New York: Wiley, 1955:160-5.

31 Greenland $S$. Interpretation and estimation of summary ratios under heterogeneity. Statistics in Medicine 1982;1:217-27.

32 Andersson JAD, Duthie JJR, Moody BP. Social and economic effects of rheumatic diseases in a mining population. Ann
Rheum Dis 1962;21:342-51

33 Waris P, Kuorinka I, Kurpa K, et al. Epidemiologic screening occupational neck and upper limb disorders. Scand $J$ Work Environ Health 1979;6 suppl 3:25-38.

34 Roos DB. Congenital anomalies associated with thoracic out syndrome. Am J Surg 1976;132:771-8.

35 Schlesselman JJ. Case-control studies. New York: Oxford Univeat sity Press, 1982.

36 Punnett L, Robins JM, Adjusting for selection bias in cros? sectional studies: soft tissue disorders in garment workers. In. Punnett L, ed. Soft tissue disorders of the upper limb. Bostogi: Harvard School of Public Health, 1985:119-46. (Thesis.)

37 Friedenberg ZB, Miller WT. Degenerative disc disease of the cervical spine. J Bone Joint Surg 1963;45A:1171-8.

38 Lawrence JS. Disc degeneration: its frequency and relation to symptoms. Ann Rheum Dis 1969;28:121-38.

39 Bremner JM, Lawrence JS, Mial WE. Degenerative joint disea in a Jamaican rural population. Ann Rheum Dis 1968;2 326-32.

40 Frykholm R, Hyde J, Norlen G, Skoglund CR. On pain sensatiẹ produced by ventral stimulation of ventral roots. Acta Physig Scand 1953;29, suppl 106.

41 Harms-Ringdahl K. On assessment of shoulder exercise and load-elicited pain in the cervical spine. Stockholm: Karolinsta Institute, 1986. (Thesis.)

42 Radin EL. Mechanical aspects of osteoarthrosis. Bull Rheum Dis 1976;26:862-5.

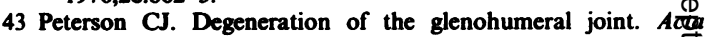
Orthop Scand 1983;54:277-83.

44 De palma AF. Surgery of the shoulder. Philadelphia: Lippinco 1950.

45 Olsson $O$. Degenerative changes of the shoulder joint and their connection with shoulder pain. Acta Chir Scand 1953, sypyo 181.

46 Neer CS. Impingement lesions. Clin Orthop 1983;173:70-6?.

47 Hagberg M. Occupational musculoskeletal stress and disorderrs the neck and shoulder: a review of possible pathophysio Int Arch Occup Environ Health 1984;53:269-78.

48 Hagberg M, Sundelin G. Discomfort and load on the upper t pezius muscle when operating a wordprocessor. Ergonombs 1986;29:1637-45.

\section{Destruction of manuscripts}

From 1 July 1985 articles submitted for publication will not be returned. Authors whose papers are rejected will be advised of the decision and the manuscripts will be kept under security for three months to deal with any inquiries and then destroyed. 